\title{
PENDAMPINGAN BELAJAR SISWA DI RUMAH MELALUI KEGIATAN BIMBINGAN BELAJAR DI DESA GUCI KARANGGENENG LAMONGAN
}

\author{
Agus Santoso', Yunni Rusmawati $^{2}$ \\ ${ }^{1}$ Pendidikan IPA, Fakultas Keguruan dan Ilmu Pendidikan, Universitas Islam Lamongan \\ ${ }^{2}$ Manajemen, Fakultas Ekonomi, Universitas Islam Lamongan \\ Jl. Veteran No.53A Lamongan \\ agus_santoso@unisla.ac.id ${ }^{1}$, yunnirusmawati@unisla.ac.id ${ }^{2}$
}

\begin{abstract}
ABSTRAK
Dalam bidang pendidikan, tidak selamanya pendidikan di sekolah berjalan lancar dan memberikan hasil sesuai dengan yang diharapkan. Berbagai upaya untuk mengatasi problematika pendidikan dapat dilakukan, salah satunya melalui kegiatan pendampingan belajar yang merupakan bagian dari bentuk pengabdian pada masyarakat. Kegiatan pengabdian masyarakat ini sebagai sarana penyampaian kebermanfaatan ilmu dan rasa kepedulian para dosen terhadap masyarakat dibidang pendidikan dalam bentuk pendampingan belajar melalui kegiatan bimbingan belajar di rumah. Tujuan dari kegiatan ini untuk meningkatkan prestasi akademik dan motivasi belajar siswa. Kegiatan ini melibatkan siswa SD dan MI yang berjumlah total 70 siswa, yang dibagi menjadi dua kelompok yaitu satu rumah untuk peminatan rumpun ilmu eksakta dan satu rumah untuk rumpun ilmu sosial. Metode pelaksanaan kegiatan secara deskriptif kualitatif. Teknik analisa data secara naratif deskriptif. Hasil kegiatan menunjukkan prestasi dan motivasi belajar siswa mengalami perkembangan yang baik. Perlunya perbaikan fasilitas dalam keberlanjutan pelaksanaan program kegiatan bimbingan belajar sehingga siswa lebih nyaman dalam belajar.
\end{abstract}

Kata Kunci: Pendampingan belajar, bimbingan belajar, Desa Guci

\begin{abstract}
In the field of education, not always education in schools runs smoothly and provides results as expected. Various efforts to overcome this educational problem can be done, one of them is through learning assistance activities that are part of a form of community service. This community service activity as a means of giving the usefulness of knowledge and a sense of care for the lecturers to the community in the field of education in the form of learning assistance through home tutoring activities. The purpose of this activity is to increase academic achievement and student motivation. This activity involved elementary school (SD) and MI students totaling 70 students, which were divided into two groups: one house for specialization in the exact sciences cluster and one house for the social science cluster. The method of implementing the activities is descriptive qualitative. Descriptive narrative data analysis technique. The results of the activities show that students learning achievements and motivation are experiencing good development. The need for improvement of facilities in the ongoing implementation of the program of tutoring activities so that students are more comfortable in learning.
\end{abstract}

Keywords: Learning assistance, tutoring, Guci Village 


\section{PENDAHULUAN}

Pendidikan merupakan usaha yang utuh dalam membangun kemampuan intelektual sekaligus kepribadian anak supaya menjadi lebih baik. Pelaksanaan kegiatan pendidikan sebagian besar telah dilakukan dalam sekolah formal, namun tidak selamanya pendidikan disekolah formal berjalan lancar dan memberikan hasil sesuai dengan yang diharapkan. Ada sebagian anak terkadang mengalami hambatan dan kesulitan dalam belajar, seperti hambatan berprestasi dan kurangnya motivasi untuk belajar. Hal ini nampak dari sebagian anak menunjukkan hasil prestasi yang kurang maksimal dan semangat motivasi untuk belajar masih kurang serta kecenderungan waktu yang digunakan untuk bermain lebih dominan daripada untuk belajar.

Kondisi yang terjadi pada masyarakat umumnya adalah menginginkan setiap anak yang telah menempuh pendidikan di sekolah formal dapat lulus dan memperoleh nilai ujian nasional yang maksimal, untuk melanjutkan kejenjang sekolah berikutnya. Berbagai macam usaha ditempuh oleh orang tua siswa untuk bisa menambah penguasaan pemahaman belajar anak yang menempuh studi di sekolah. Pendidikan secara formal saja dirasa tidak cukup untuk meningkatkan pemahaman siswa dalam belajar, sehingga banyak yang menempuh pendidikan non-formal pada lembaga bimbingan belajar di luar jam belajar sekolah (Ari, et al., 2015). Fenomena tersebut seakan menggambarkan bahwa pendidikan formal tidaklah cukup sebagai bekal untuk menyiapkan peserta didik dalam menghadapi berbagai macam ujian seperti ujian nasional (Ari, et al., 2015).

Hal tersebut tentu diperlukan upaya nyata dari semua lapisan elemen masyarakat untuk mengatasi problematika dalam bidang pendidikan yang implementasinya dapat dilakukan di sekolah, di rumah, maupun di lingkungan. Berbagai upaya untuk mengatasi problematika pendidikan ini dapat dilakukan, salah satunya melalui kegiatan pendampingan belajar yang merupakan bagian dari bentuk pengabdian pada masyarakat. Bentuk pengabdian melalui pendampingan belajar ini pernah dilakukan oleh Agustina et al. (2019) yang dilakukan selama 1 bulan. Hasil kegiatan pengabdian pada masyarakat tersebut mendapat sambutan positif dari pihak sekolah, terutama karena pelatihan ini sesuai dengan kebutuhan mereka dan motivasi peserta pelatihan cukup antusias. Selanjutnya, Dewi et al. (2016) melakukan pengabdian melalui bimbingan belajar dan hasilnya diperoleh sebanyak $85 \%$ dari siswa-siswi bimbingan belajar lebih memahami dan menguasai materi matematika serta dapat mengaplikasikan dalam kehidupan sehari-hari. 
Kegiatan pendampingan belajar melalui bimbingan belajar merupakan proses pemberian bantuan atau pertolongan baik bagi individu maupun kelompok oleh seorang atau lebih pembimbing yang memiliki keahlian di bidang tersebut dalam menentukan pilihan, penyesuaian serta pemecahan masalah belajar yang berkaitan dengan perubahan tingkah laku sebagai akibat dari pengalaman, latihan maupun rangsangan (Rosaria, et al., 2017). Pendampingan belajar melalui kegiatan bimbingan belajar dapat meningkatkan prestasi sekaligus motivasi belajar. Hal ini sejalan dengan hasil penelitian Zumaroh (2013) yang menyatakan bahwa motivasi belajar siswa underachiever dapat ditingkatkan melalui layanan bimbingan kelompok yang tepat. (Zumaroh, 2013). Untuk meningkatkan motivasi siswa selain bimbingan belajar untuk memotivasi, perlu adanya bimbingan secara mental dengan memberikan motivasi positif. Pemberian reward tampaknya memberikan kontribusi yang baik. Reward yang diberikan tidak selalu berupa barang melainkan dapat berupa pujian atau konsekuensi positif (Erlita, 2014).

Siswa mengikuti kegiatan bimbingan belajar disebabkan oleh beberapa faktor. Berdasarkan faktor geografis diperoleh gambaran bahwa kedekatan lokasi rumah menjadi prioritas dan faktor lainnya menyatakan metode bimbingan menjadi hal utama. Selain itu, terdapat perbedaan preferensi pada indikator kedekatan lokasi sekolah dan biaya kegiatan pada tiap daerah (Yanuar, et al. 2018). Selain faktor tersebut, menurut Eriany, et al. (2014) mengikuti program bimbel banyak dipengaruhi oleh faktor motivasi intrinsik, yaitu sebesar 89.12\%. Besarnya faktor tersebut ada kemungkinan disebabkan oleh adanya rasa ketakutan menghadapi ujian, kurang adanya rasa percaya diri, serta harapan yang tinggi untuk diterima ditingkat pendidikan yang lebih tinggi. (Eriany, et al. 2014).Lembaga bimbingan belajar di luar sekolah menjadi alternatif para siswa untuk mendapatkan materi yang belum diajarkan disekolah (Dwi, 2013). Keputusan untuk mengikutsertakan anak di lembaga kursus atau bimbingan belajar merupakan keputusan yang tepat bagi anak-anak. Di sana mereka bisa memperoleh ilmu yang tidak sempat diajarkan oleh guru di sekolah. Akan tetapi, tidak semua anak bisa mengikuti les ataupun bimbingan belajar. Hal tersebut terjadi di lingkungan tempat tinggal anak di Desa Guci Kecamatan Karanggeneng yang jauh dari pusat perkotaan dan karena mahalnya biaya bimbingan belajar. Dengan melihat kendala tersebut, membuat para dosen Universitas Islam Lamongan merasa terpanggil untuk melakukan pengabdian di daerah tersebut. Kegiatan pengabdian masyarakat ini sebagai sarana penyampaian kebermanfaatan ilmu dan rasa kepedulian para dosen terhadap masyarakat dibidang pendidikan dalam bentuk 
pendampingan melalui kegiatan bimbingan belajar di rumah. Tujuan dari kegiatan ini untuk meningkatkan prestasi akademik dan motivasi belajar siswa.

\section{METODE}

Pendampingan siswa melalui kegiatan bimbingan belajar ini dilaksanakan di rumah penduduk Desa Guci Kecamatan Karanggeneng Kabupaten Lamongan. Rumah yang dibutuhkan berjumlah 2 rumah dengan kapasitas masing-masing dapat menampung 35 siswa. Kegiatan ini diikuti oleh partisipan siswa SD dan MI di Desa Guci dengan jumlah total siswa yang mengikuti kegiatan bimbingan belajar setiap hari sebanyak 70 siswa, yang terdiri atas 35 siswa dari SD dan 35 siswa dari MI. Dasar pemilihan siswa yang bisa mengikuti kegiatan bimbingan belajar dengan teknik purposive random sampling dan atas arahan dan rekomendasi pihak sekolah. Kegiatan ini dibagi menjadi dua kelompok yaitu satu rumah untuk peminatan rumpun ilmu eksakta dan satu rumah selanjutnya untuk rumpun ilmu sosial, sehingga dalam satu rumah memungkinkan untuk anak sekolah di SD dan MI untuk bercampur karena peminatan kedua rumpun ilmu tersebut. Kegiatan ini dilakukan oleh dua dosen dari Universitas Islam Lamongan yang bertindak sebagai pemberi materi (tutor). Dosen yang pertama berlatar belakang dari ilmu eksakta dan dosen yang kedua berlatar belakang dari ilmu sosial. Kegiatan ini juga dibantu oleh beberapa mahasiswa untuk mengkondisikan jalannya program kegiatan.

Fasilitas yang digunakan untuk menunjang pelaksanaan kegiatan adalah dua rumah penduduk yang sesuai kriteria, papan tulis sederhana, alat tulis menulis, buku pelajaran siswa, dan beberapa makanan ringan (snack) dan permen sebagai reward (hadiah) untuk siswa. Pelaksanaan kegiatan ini dilakukan selama bulan Juli dan Agustus 2019, pada pukul 18.00 hingga 21.00 WIB. Pelaksanaan kegiatan bimbingan belajar ini menggunakan lima tahapan, yaitu: (1) pemotivasian siswa dalam belajar melalui motivasi berorientasi materi dan motivasi tentang kehidupan berupa cerita-cerita inspiratif, (2) ceramah/penjelasan materi, (3) tanya jawab, (4) permainan berupa kuis yang menantang (kuis siapa berani), (5) pemberian reward (hadiah) berupa pujian/penghargaan secara lisan dan berupa barang. Metode penelitian pelaksanaan kegiatan ini secara deskriptif kualitatif. Teknik pengumpulan secara tes untuk mengetahui perkembangan prestasi belajar siswa, dan secara non tes dengan wawancara dan menggunakan lembar observasi untuk mengetahui motivasi belajar siswa. Jenis data dalam penelitian ini tergolong data kualitatif. Teknik analisa data secara naratif deskriptif. 


\section{HASIL DAN PEMBAHASAN}

Hasil dari kegiatan pengabdian ini berupa pendampingan siswa melalui kegiatan bimbingan belajar yang dilaksanakan di rumah penduduk di Desa Guci. Kegiatan pengabdian ini merupakan salah satu program pengabdian masyarakat bagi Dosen sebagai upaya pelaksanaan tri dharma perguruan tinggi. Kegiatan pengabdian kepada masyarakat ini memberikan banyak manfaat, wawasan dan pengetahuan kepada anak-anak di Desa Guci, terutama dalam meningkatkan prestasi dan motivasi belajar. Pelaksanaan kegiatan bimbingan belajar ini menggunakan 5 tahapan, yaitu: (1) pemotivasian siswa dalam belajar melalui motivasi berorientasi materi dan motivasi tentang kehidupan berupa cerita-cerita inspiratif, (2) ceramah atau penjelasan materi, (3) tanya jawab, (4) Permainan berupa kuis yang menantang (kuis siapa berani), (5) pemberian reward (hadiah) berupa pujian/penghargaan secara lisan dan berupa barang.

Tahapan pemotivasian siswa dalam belajar melalui dua jenis motivasi, yaitu motivasi berorientasi materi dan motivasi tentang kehidupan berupa cerita-cerita inspiratif. Motivasi berorientasi materi dilakukan dengan cara memberikan suatu kegiatan motivasi yang sesuai dengan materi yang akan dipelajari, misalnya dalam kelompok eksakta berupa penyajian fenomena alam yang unik, demonstrasi peragaan alat-alat praktikum, sedangkan dalam kelompok ilmu sosial berupa sajian fenomena dimasyarakat, kebudayaan, dan perilaku sosial dimasyarakat pada suatu daerah yang memiliki kearifan lokal tertentu yang dapat merangsang siswa untuk siap menerima materi. Hal ini akan mendorong siswa untuk bertanya-tanya dan termotivasi pada materi kegiatan yang akan dipelajari. Motivasi kehidupan berupa ceritacerita inspiratif dengan cara pemateri dalam hal ini dosen memberikan kisah-kisah inspiratif, baik yang dialami oleh orang lain ataupun pengalaman langsung yang dialami oleh pemateri sendiri, seperti pengalaman mendapatkan beasiswa dan beberapa penghargaan serta kemudahan dalam menciptakan lapangan kerja karena berkat menempuh pendidikan tinggi. Hal ini akan mendorong siswa untuk termotivasi pada dunia pendidikan dan keinginan untuk melanjutkan pendidikan tinggi.

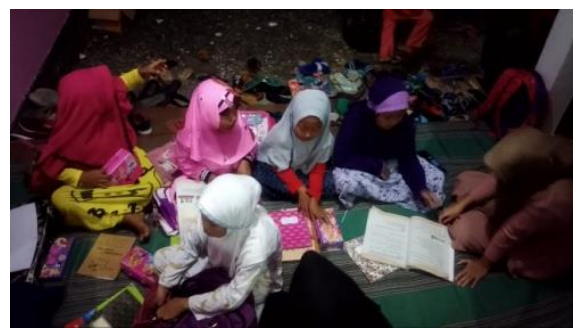

Gambar 1. Kegiatan bimbingan belajar di rumah warga Desa Guci 
Tahapan ceramah atau penjelasan materi berisi penjelasan dari pemateri baik oleh dosen rumpun ilmu eksakta dan ilmu sosial. Pemberian mengacu pada buku pelajaran siswa yaitu sesuai kurikulum 2013 yang telah direvisi. Pemberian materi diurutkan sesuai jenjang pendidikan di SD/MI dalam hal ini dilaksanakan untuk jenjang kelas V dan VI secara bergantian. Pemilihan terhadap jenjang kelas tersebut karena pada kelas V dan kelas VI telah mendekati ujian nasional (UN) dan materi sudah sangat kompleks.

Tahapan tanya jawab dilaksanakan untuk mengetahui sejauh mana pemahaman siswa terhadap penjelasan yang telah dipelajari sebelumnya. Siswa diberikan kesempatan untuk bertanya dan pemateri (dosen) memberikan kesempatan siswa lain untuk menjawab pertanyaan tersebut. Tugas pemateri adalah meluruskan jawaban dari siswa, dan menjawab bilamana ada pertanyaan yang belum bisa terjawab. Bagi siswa yang bertanya dan menjawab diberikan poin khusus berupa bintang untuk memotivasi keaktifan siswa.

Tahapan permainan berupa kuis yang menantang (kuis siapa berani) bertujuan untuk mengasah kemampuan siswa dengan persoalan-persoalan yang menantang. Tahapan permainan ini berupa petunjuk untuk melengkapi kata yang kosong dengan beberapa huruf atau angka setelah pemateri membacakan teka-teki dengan uraian kalimat-kalimat untuk menggiring kepada jawaban sesuai dengan yang diinginkan. Tahapan ini juga digunakan untuk mengetahui sejauh mana kemampuan siswa dalam menerima kegiatan pembelajaran. Hasil dari tahapan juga digunakan untuk memperoleh tambahan poin bintang untuk ditukarkan dengan reward diakhir kegiatan pembelajaran.

Tahapan pemberian reward (hadiah) berupa pujian/penghargaan secara lisan dan berupa barang. Tahapan ini bertujuan untuk merangsang keaktifan dan sikap antusias siswa dalam mengikuti kegiatan belajar. Reward yang diberikan berupa pujian/penghargaan secara lisan bagi siswa yang mengikuti kegiatan belajar hingga akhir dengan tertib, selain itu mereka juga mendapatkan permen, sedangkan reward berupa barang (makanan ringan) diperuntukkan bagi siswa yang memperoleh poin bintang terbanyak. Pemberian reward memberikan kontribusi yang baik dalam meningkatkan motivasi belajar siswa, hal ini sesuai dengan penelitian yang dilakukan Erlita (2014).

Perkembangan prestasi belajar siswa rata-rata menunjukkan perkembangan yang positif menuju ke arah yang lebih baik. Hal tersebut berdasarkan hasil tes berupa tanya jawab secara lisan berdasarkan materi yang telah dipelajari. Selain itu, dapat dilihat dari perkembangan nilai harian siswa di buku paket, LKS, dan buku tugas siswa yang digunakan untuk ke 
sekolah rata-rata mengalami kenaikan. Hal ini menunjukkan bahwa kegiatan bimbingan belajar mampu meningkatkan prestasi siswa. Namun, masih ditemui ada sebagian kecil siswa yang perkembangan nilainya cenderung masih tetap, dan bahkan ada siswa yang nilainya dibawah kriteria ketuntasan minimal (KKM). Hal tersebut ternyata disebabkan karena kedisiplinan siswa dalam mengikuti bimbingan belajar masih kurang, dan terdapat satu siswa yang lupa tidak membawa tugas ke sekolah, sehingga terpaksa nilainya dibawah KKM pada nilai tugas.

Perkembangan motivasi belajar siswa menunjukkan hasil yang positif. Hasil perkembangan ini dilihat berdasarkan hasil wawancara secara lisan pada siswa. Sebagian besar siswa menunjukkan keinginan yang kuat untuk terus berprestasi dan menempuh hingga pendidikan tinggi. Beberapa siswa menunjukkan cita-cita yang kuat untuk menjadi seorang dokter, pilot, polisi, presiden, direktur, pelaut, menteri, bidan, hingga guru. Berdasarkan hasil pengamatan melalui lembar observasi, menunjukkan sikap antusias siswa dalam mengikuti kegiatan bimbingan belajar. Siswa menjadi lebih termotivasi ketika belajar secara bersamasama, bahkan ada yang mengatakan bahwa pembelajaran dengan pola bimbingan belajar seperti itu terasa menyenangkan.

Kendala yang dihadapi selama pelaksanaan program tersebut adalah diperlukannya fasilitas yang lebih memadai seperti penerangan lampu, dan pendingin ruangan, mengingat kegiatan tersebut pelaksanaannya dimalam hari jadi membutuhkan beberapa lampu penerangan di sudut-sudut ruangan. Pendingin ruangan juga diperlukan terkait dengan jumlah siswa sebanyak 35 siswa per rumah, maka akan meningkatkan suhu ruangan di dalam rumah jika dipakai terlalu lama. Upaya keberlanjutan program dengan mengadakan fasilitas yang memadai untuk meningkatkan kegiatan literasi siswa di luar sekolah melalui pelaksanaan kegiatan bimbingan belajar, sehingga siswa menjadi lebih nyaman dalam belajar.

\section{SIMPULAN}

Pelaksanaan kegiatan pendampingan belajar siswa di rumah melalui bimbingan belajar di Desa Guci telah terlaksana dengan menggunakan lima tahapan, yaitu: (1) pemotivasian siswa dalam belajar melalui motivasi berorientasi materi dan motivasi tentang kehidupan berupa cerita-cerita inspiratif, (2) ceramah/penjelasan materi, (3) tanya jawab, (4) permainan berupa kuis yang menantang (kuis siapa berani), (5) pemberian reward (hadiah) berupa pujian/penghargaan secara lisan dan berupa barang. 
Perkembangan motivasi belajar siswa menunjukkan hasil yang positif disertai sikap antusias siswa dalam mengikuti kegiatan bimbingan belajar. Perkembangan prestasi belajar siswa rata-rata menunjukkan perkembangan yang positif menuju ke arah yang lebih baik. Kendala yang dihadapi selama pelaksanaan program tersebut adalah masih diperlukannya fasilitas yang lebih memadai seperti penerangan lampu, dan pendingin ruangan sehingga siswa menjadi lebih nyaman dalam belajar.

\section{DAFTAR PUSTAKA}

Ari, S. P M., Ardhi, W. (2015). Analisis Kepuasan Siswa Terhadap Kegiatan Pembelajaran Biologi Pada Sekolah Formal Dan Lembaga Bimbingan Belajar Non-Formal Di Kota Madiun. Jurnal Penelitian LPPM IKIP PGRI Madiun. Vol. 3 No. 1. , 1-5.

Agustina, E., Rohmah, A, \& Kuspiyah, H. (2019). Pendampingan Bimbingan Belajar Bahasa Inggris dan Bakti Sosial di Yayasan Pendidikan dan Sosial Roudlotut Thullab. Jurnal Indonesia Mengabdi, 1 (1), 1-5.

Dewi, V. S., \& Maharani, S. (2016). IBM Membangun "Desa Cermat" Melalui Bimbingan Belajar dalam Meningkatkan Hasil Belajar Matematika Siswa. Jurnal Terapan Abdimas. Vol. 1 No. 1., 1-7.

Rosaria, D., Novika, H. (2017). Bimbingan Belajar Bahasa Inggris Bagi Anak Usia Sekolah Dasar (6-12 Tahun) Di Desa Semangat Dalam Rt.31 handil Bhakti. Jurnal Al-Ikhlas. ISSN : 2461-0992 Volume 2 Nomor 2.

Zumaroh,A.Khasanah. (2013) Meningkatkan Motivasi Belajar Siswa Underachiever Melalui Layanan Bimbingan Kelompok pada Siswa SD Negeri Pekunden Semarang. Under Graduates Thesis, Universitas Negeri Semarang.

Erlita, Brigitta T.A. (2014). Slow Learner: Bagaimana Memotivasinya dalam Belajar. Jurnal Kependidikan Widya Dharma. Vol 27, No. 01. (1-8).

Yanuar, Briantama R., Sriyanto Bambang E.P. (2018). Preferensi Pelajar Smp Menentukan Lokasi Lembaga Bimbingan Belajar di Kawasan Perkotaan Yogyakarta. Jurnal Bumi Indonesia. Volume: 7, No: 03, (1-7).

Eriany, Prahesti., Hernawati, Lucia., Goeritno, Haryo. (2014). Studi Deskriptif Mengenai Faktor-Faktor yang Mempengaruhi Motivasi Mengikuti Kegiatan Bimbingan Belajar pada Siswa SMP di Semarang. Jurnal Psikodimensia Kajian Ilmiah Psikologi. Vol 13, No 1 (2014) $115-130$

Dwi, Novitasari P. (2013). Konstruksi Sosial Peserta Didik pada Lembaga Bimbingan NonFormal. Jurnal Paradigma. Vol 1, No 1, 7-15. 